\title{
mRNAs biomarker related to the control of proliferation and cell death in HepG2/C3A spheroid and monolayer cultures treated with piperlongumine
}

Bruna Isabela Biazi, Thalita Alves Zanetti, Lilian Areal Marques, Adrivanio Baranoski, Giuliana Castello Coatti and Mário Sérgio Mantovani*

\begin{abstract}
Background: Cell culture (spheroid and 2D monolayer cultures) is an essential tool in drug discovery. Piperlongumine (PLN), a naturally occurring alkaloid present in the long pepper (Piper longum), has been implicated in the regulation of GSTP1 activity. In vitro treatment of cancer cells with PLN increases ROS (reactive oxygen species) levels and induces cell death, but its molecular mode of action has not been entirely elucidated.

Methods: In this study, we correlated the antiproliferative effects (2D and 3D cultures) of PLN (CAS 20069-09-4, Sigma-Aldrich) with morphological and molecular analyses in HepG2/C3A cell line. We performed assays for cytotoxicity (MTT), comet assays for genotoxicity, induction of apoptosis, analysis of the cell cycle phase, and analysis of the membrane integrity by flow cytometry. Relative expression of mRNA of genes related to proliferation, apoptosis, cell cycle control, metabolism of xenobiotics, and reticulum endoplasmic stress.

Results: PLN reduced the cell proliferation by the cell cycle arrest in G2/M. Changes in the mRNA expression for CDKN1A (4.9x) and CCNA2 (0.5x) of cell cycle control genes were observed. Cell death occurred due to apoptosis, which may have been induced by increased expression of proapoptotic mRNAs (BAK1, 3.1x; BBC3, 2.4x), and by an increase in 9 and 3/7 active caspases. PLN induced cellular injury by ROS generation and DNA damage. DNA damage induced MDM2 signaling (3.0x) associated with the appearance of the monastral spindle in mitosis. Genes associated with ROS degradation also showed increased mRNA expression (GSR, 2.0x; SOD1, 2.1x). PLN induce endoplasmic reticulum stress with the increase in the mRNA expression of ERN1 (4.5x) and HSPA14 (2.2x). The xenobiotic metabolism showed increased mRNA expression for CYP1A2 (2.2x) and CYP3A4 (3.4x). In addition to 2D culture, PLN treatment also inhibited the growth of 3D culture (spheroids).

Conclusion: Thus, the findings of our study show that several gene expression biomarkers (mRNAs) and monastral spindle formation indicated the many pathways of damage induced by PLN treatment that contributes to its antiproliferative effects.
\end{abstract}

Keywords: Anticancer, Phytochemical, Toxicity, Transcription

\footnotetext{
*Correspondence: biomsm@uel.br

Department of General Biology, Center of Biological Sciences, Londrina State University - UEL, Rodovia Celso Garcia Cid, Pr 445 Km 380, Londrina, Paraná, Brazil
}

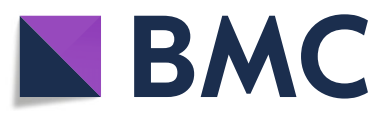

(ㅇ The Author(s). 2020 Open Access This article is licensed under a Creative Commons Attribution 4.0 International License, which permits use, sharing, adaptation, distribution and reproduction in any medium or format, as long as you give appropriate credit to the original author(s) and the source, provide a link to the Creative Commons licence, and indicate if changes were made. The images or other third party material in this article are included in the article's Creative Commons licence, unless indicated otherwise in a credit line to the material. If material is not included in the article's Creative Commons licence and your intended use is not permitted by statutory regulation or exceeds the permitted use, you will need to obtain permission directly from the copyright holder. To view a copy of this licence, visit http://creativecommons.org/licenses/by/4.0/ 


\section{Background}

Cancers occur due to several distinct mechanisms of alterations in the expression of proliferation control genes and cell death genes. Therefore, a clear understanding of the mechanisms of cell death induction by candidate chemotherapeutic compounds is essential for the development of specific and effective anticancer therapies [1]. Specific target drugs are developed only after studying the molecular mechanisms of cell death and proliferation and by understanding the differences in each type of cancer [2,3]. Consequently, drugs that have less adverse effects and that decrease the incidence of relapse have been produced for some types of cancers [4-6]. However, since several cancers, for example, triple negative breast cancer, are still treated with nonspecific therapies, it is necessary to study new drug candidates and their specific mechanisms of action.

Drug-induced cell death can occur by several mechanisms. The regulation of apoptosis and autophagy comprise the most well-known molecular process, modulating the activity of BCL-2 family of proteins-one of the main mechanisms of induction of death [7-9]. The BCL-2 family comprises a group of genes encoding pro or anti-apoptotic proteins, and the imbalance between the amounts of these proteins within the cell can dissipate the signaling of death by one of the pathways of apoptosis (intrinsic pathway). The extrinsic pathway of apoptosis involves the action of death-inducing molecules (e.g., TNF- $\alpha$, Fas ligand) binding to external receptors on the plasma membrane; the intracellular signaling is then dissipated after the binding of adaptor molecules FADD and TRADD in the internal region of the receptors $[10,11]$. In autophagy, about 27 genes (ATG genes) are involved in the execution of autophagic pathways, while the other 40 genes related to other pathways may also be involved in autophagy $[12,13]$.

Piperlongumine (PLN) is an alkaloid found in several species of peppers and the antiproliferative action of this compound is its most important biological property. The anticancer activity of piperlongumine has been elucidated through studies using cell lines and animal models. The in vitro cytotoxicity of PLN using cell lines has already been attested by several studies in the literature, which used, for example, colorimetric assays [1416]. It is also known that the harmful effect of PLN occurs due to the increase in reactive oxygen species (ROS) induced by this drug [15, 17-20]. In addition, oxidative stress induced by PLN is associated with the damage caused by genetic material $[19,21]$. It is also known that the drug induces cell cycle arrest in G2/M [22-25] and that these events are linked to cell death induction by apoptosis and/or autophagy, for example, in cell cultures of breast cancer [14, 26, 27], lung [28-31], and kidney $[26,30]$. In this study, these effects of PLN could be related to changes in the expression of genes involved in these processes.

HepG2/C3A is a widely used cell line for studying drug-action mechanisms because this cell line shows a strong xenobiotic metabolic activity. In this study, we evaluated the effects of PLN on HepG2/C3A cells based on parameters of cytotoxicity, genotoxicity, proliferation, cell death, oxidative stress, and mitochondrial potential. Further, these effects were correlated to the findings of the relative expression of the genes involved in these processes. This enabled us to understand the morphological and molecular mechanisms of action of PLN, thereby contributing to a better understanding of its applicability as a future chemotherapeutic agent.

\section{Methods}

\section{Chemical agents}

PLN $\left(\mathrm{C}_{17} \mathrm{H}_{19} \mathrm{NO}_{5}\right)$ was obtained from Sigma-Aldrich $(\geq 97 \%$; Cat. No.: SML0221, extracted from Piper longum Linn), dissolved in dimethyl sulfoxide (DMSO, $30 \mathrm{mM}$ ), and stocked at $-20^{\circ} \mathrm{C}$. The solution was diluted in the culture medium for use in the treatments, and the highest concentration used $(50 \mu \mathrm{M})$ had $0.17 \%$ DMSO. The vehicle control treatment was performed with this same concentration of DMSO and $0 \mu \mathrm{M}$ PLN. Doxorubicin (DXR-Pharmacia-CAS 23214-92-8) and tert-butyl (Sigma-Aldrich, Cat. No. 458139) were used in the comet assays and for ROS generation, respectively, as positive controls, and camptothecin (CPT; Merck Millipore; CAS 7689-03-4) was used for the other assays.

\section{Cell culture}

The human hepatocellular carcinoma (HepG2/C3A) lineage was obtained from the Cell Bank of Rio de Janeiro free of mycoplasma. Cells were maintained in DMEM (Gibco, CAT-12800-017) supplemented with $10 \%$ fetal bovine serum (FBS, Gibco, CAT-12657-029) and $0.1 \%$ penicillin/streptomycin (Invitrogen CAT15240-096), and kept in a humid oven with $5 \% \mathrm{CO}_{2}$ at $37^{\circ} \mathrm{C}$. In all tests, the cells were seeded and maintained for $24 \mathrm{~h}$ for stabilization before receiving the treatments. The cell density used in the assays was determined by titration using the xCELLigence Real-Time Cell Analyzer. Approximately $2.5 \times 10^{4}$ cells/well were used in 96-well plates for the MTT assays and active caspase analysis, $1.25 \times 10^{5}$ cells/well in 24 -well plates for counting rosettes, $61.7 \times 10^{5}$ cells/well in 6-well plates for cytometry, comet, RNA extraction and micrographs, and 650 cells/ well in 96-well plates for the 3D assay.

\section{Cytotoxicity evaluation using MTT assay}

Cell viability was estimated using the MTT assay according to [32] with modifications. After $24 \mathrm{~h}$ of treatment $(0-50 \mu \mathrm{M}$ PLN and $1 \mu \mathrm{M} \mathrm{CPT})$, the cells were incubated 
for $4 \mathrm{~h}$ in serum-free medium containing MTT $(500 \mu \mathrm{g} /$ $\mathrm{mL}$ ). The culture medium was removed and the formazan crystals adhering to the bottom of the plate were diluted in DMSO for spectrophotometer reading (TP Reader; Thermo Plate, China) at $540 \mathrm{~nm}$. Cell viability was estimated using the following formula: [(treatment absorbance/control absorbance) $\times 100]$. The $\mathrm{IC}_{50}$ was determined using the GraphPad Prism program. The experiment was performed in three replicate plates containing six replicates/treatment/plate.

\section{Cell evaluation by flow cytometry}

Cell cycle and cell death by apoptosis were evaluated using the Guava EasyCyte flow cytometer (Merck Millipore). After treatment $(0-40 \mu \mathrm{M} P L N)$, cells were harvested by trypsinization, centrifuged at $1000 \mathrm{rpm}$ for 5 min, and resuspended in $500 \mu \mathrm{L}$ PBS. To evaluate cell death by apoptosis, the Pharmingen ${ }^{\text {Tw }}-\mathrm{PE}$ Annexin V Apoptosis Detection Kit I kit (Cat. No.: 559763) was used according to the manufacturer's protocol; the percentages of viable cells (absence of annexin and 7-AAD labeling), initial apoptosis (labeled with annexin), late apoptosis (labeled with annexin and 7-AAD), and necrosis (labeled with 7-AAD) were determined. To evaluate the cell cycle, $5 \mu \mathrm{L}$ RNase $(2 \mu \mathrm{g} / \mathrm{mL}$, Invitrogen; Cat. No.: 12091-021) was added to $100 \mu \mathrm{L}$ cell suspension and maintained at $37^{\circ} \mathrm{C}$ for $30 \mathrm{~min}$. For cell lysis and DNA labeling, the Guava Cell Cycle Reagent Kit (Cat. No.: 4500-0220) was used according to the manufacturer's protocol. The percentages of cells in different phases of the cell cycle (G1, S, and G2/M) were determined according to the fluorescence intensity emitted by each cell. For each assay, 5000 cells were analyzed per treatment/experiment. The assays were performed in three experiments simultaneously.

\section{Obtaining micrographs}

The phase contrast system was used to observe the morphological changes and cell density; the fluorescence system was used to capture fluorescence from the red filter (blue laser) for the detection of rhodamine 123 [33], and blue (UV) fluorescence was used for DNA labeling using Hoechst 33342 [34, 35]. After $24 \mathrm{~h}$ of treatment (0$40 \mu \mathrm{M}$ of PLN) with $2 \mu \mathrm{l}$ of rhodamine $123(1 \mathrm{mg} / \mathrm{mL}$ Cat. No.: R8004, Sigma-Aldrich) and $1 \mu \mathrm{L}$ of Hoechst 33342 (2 mg/mL, Cat. No. B2261), the culture medium was homogenized and the cultures were incubated at $37^{\circ} \mathrm{C}$ for $20 \mathrm{~min}$. Thereafter, the culture medium was removed, the culture was washed once using $\mathrm{PBS}$ at $37^{\circ} \mathrm{C}$, $1 \mathrm{~mL}$ of PBS was added, and the culture was then analyzed under the EVOS ${ }^{\bullet}$ Microscope FL Auto Cell Imaging System 4 microscope (Thermo Fisher).

\section{Spindle cell count in the monastral format}

After $24 \mathrm{~h}$ of treatment (0-40 $\mu \mathrm{M}$ PLN), $1 \mu \mathrm{L}$ of Hoechst $33342(2 \mathrm{mg} / \mathrm{mL}$, Cat. No. B2261) was added directly to the culture medium, which was homogenized and incubated at $37^{\circ} \mathrm{C}$ for $20 \mathrm{~min}$. The culture medium was removed, the culture was washed once using Phosphatebuffered saline (PBS) at $37^{\circ} \mathrm{C}$, and $1 \mathrm{~mL}$ of PBS was added to the cultures. Then, fluorescence microscopy was performed for counting the cells in the rosette format. Approximately 500 cells were analyzed per treatment/replicate in three simultaneous replicates.

\section{Spheroid formation (3D culture)}

To obtain spheroid-shaped 3D cultures, $50 \mu \mathrm{L}$ of agarose diluted in culture medium (1.5\%) was used to cover the wells of the 96-well plate. Approximately 650 cells per well diluted in $50 \mu$ l culture medium were seeded. The plate was subjected to centrifugation at $2500 \mathrm{rpm}$ for 5 min so that the cells remained centralized to the bottom of each well. After $48 \mathrm{~h}$, another $100 \mu \mathrm{L}$ of culture medium was added. After another $72 \mathrm{~h}$, spherical structures were formed. Thereafter, $100 \mu \mathrm{L}$ of medium was removed and $150 \mu \mathrm{L}$ of fresh culture medium containing the PLN treatments were added to final concentrations of $0,10,20$, and $40 \mu \mathrm{M}$. The volume of the spheroids was determined using the formula: $\mathrm{V}=\left(4 \pi \mathrm{r}^{3}\right) / 3$, where $r$ (radius) was determined using the ImageJ software in micrograph processing. The images of the spheroids were obtained by EVOS FL microscopy in phase contrast (100× magnification) and captured at 24,48 , and $72 \mathrm{~h}$ after the treatments. The experiments were performed on three replicate plates containing six replicates of treatment/plate.

\section{Genotoxicity assessment}

The comet assay [36] was used to analyze PLN's potential to cause damage to the genetic material. After $3 \mathrm{~h}$ of treatment ( 0 and $40 \mu \mathrm{M}$ PLN), the cells were trypsinized, centrifuged (1000 rpm for $5 \mathrm{~min}$ ), and resuspended in $200 \mu \mathrm{L}$ of culture medium. Cells were then diluted into low melting point agarose $(0.5 \%)$ and distributed into pregelatinized sheets with common agarose. Cells were lysed (lysis solution: $2.25 \mathrm{M} \mathrm{NaCl}, 90 \mathrm{mM}$ EDTA, $9 \mathrm{mM}$ Tris- $\mathrm{HCl}, 10 \% \mathrm{DMSO}$, and $1 \%$ Triton X-100) for $60 \mathrm{~min}$ at $4{ }^{\circ} \mathrm{C}$ and subjected to alkaline conditions (electrophoresis buffer: EDTA-titriplex, $1 \mathrm{mM}$; $\mathrm{NaOH}, 0.3 \mathrm{~N}$ ) for 20 min. Electrophoresis was performed at pH 13, $25 \mathrm{~V}, 300$ $\mathrm{mA}$ for $20 \mathrm{~min}$. Then, the sheets were fixed with absolute ethanol and stored at $4{ }^{\circ} \mathrm{C}$. For the analysis, $100 \mu \mathrm{L}$ of ethidium bromide solution $(2 \mu \mathrm{g} / \mathrm{mL})$ was used. Micrographs were obtained with a 200-fold increase, and the comets were analyzed using the CometScore ${ }^{\circ}$ program. The tail moment parameter was used for the 
analysis. Approximately 100 cells were analyzed for each treatment/replicate in three experimental replicates.

\section{Reactive oxygen species and mitochondrial activity detection}

These assays use the fluorescence detection emitted by $2^{\prime}, 7^{\prime}$-dichlorofluorescin diacetate (DCFDA) after ROS oxidation and Rhodamine-123 that selectively stains mitochondria depending on the membrane potential. After $24 \mathrm{~h}$ of treatment $(0-40 \mu \mathrm{M}$ of PLN), DCFDA $(25 \mu \mathrm{M}$ of final concentration) or rhodamine $123(1 \mathrm{mg} / \mathrm{mL})$ were added to the culture media, and the samples were incubated for $20 \mathrm{~min}$ at $37^{\circ} \mathrm{C}$. Thereafter, the cells were harvested and centrifuged for $5 \mathrm{~min}$ at $1000 \mathrm{rpm}$. Fluorescence (5000 cells) was detected using the Guava EasyCyte flow cytometer (Merck Millipore) in green filter (blue laser) for DCFDA and red filter (blue laser) for rhodamine 123. The experiments were performed in three simultaneous repetitions.

\section{Relative gene expression analysis using RT-qPCR}

This assay was performed to verify the changes in the pattern of the gene transcript expression that are related to the molecular pathways previously evaluated in the assays. The gene primer sequences used in the real-time reactions are mentioned in the Supplementary Material (Table S1). The following genes were analyzed: genes of apoptosis (BAK1, BAX, BBC3, BCLXL, CASP3, CASP7, CASP8, and CASP9), cell cycle (CCNA2, CCNB1, CCNB2, CDK1, CDKN1A, and TP53), DNA damage signaling (CHK1, CHK2, GADD45A, H2AFX, and MDM2), proliferation and death control (HNF4A, MTOR, MYC, TNF, and TRAF2), oxidative stress (CAT, GPX1, GSR, and SOD1), ERS (ABL1, ATF6, EIF2AK3, ERN1, HSPA14, and HSPA5), and xenobiotic metabolism (CYP1A2, CYP2C19, CYP2D6, and CYP3A4). After $12 \mathrm{~h}$ of treatment ( 0 and $20 \mu \mathrm{M}$ PLN), total RNA was extracted using the RNeasy Kit (Cat. No.: 74106, Qiagen) as per the manufacturer's specifications. The samples were quantified spectrophotometrically, and the purity was estimated by measuring the absorbance at $260 \mathrm{~nm} / 280 \mathrm{~nm}$ (validated when between 1.8 and 2.1). The integrity of the RNA was verified in 1\% agarose gel.

The synthesis of cDNA was performed according to the protocol of [37]. The real-time reactions were performed in the CFX96 Touch $^{\text {Tx }}$ Real-Time PCR Detection System (Bio-Rad). For this, the SsoAdvancedTM SYBR ${ }^{\circ}$ Green Supermix (Cat. No.: 172-5260 Bio-Rad) was used with a final volume of $11 \mu \mathrm{L}$ (5 pmol of each primer and $250 \mathrm{ng}$ of cDNA). The following conditions were used for the real-time PCR: $95^{\circ} \mathrm{C}$ for $5 \mathrm{~min}$ and $45 \mathrm{cy}$ cles of $95^{\circ} \mathrm{C} / 15 \mathrm{~s}, 60^{\circ} \mathrm{C} / 20 \mathrm{~s}, 72^{\circ} \mathrm{C} / 20 \mathrm{~s}$. GAPDH and $R P L 13 A$ were used as the housekeeping genes in all the reactions. The experiments were done in three simultaneous repetitions.

\section{Active caspase evaluation}

This assay was performed to detect active caspases after PLN treatment. After $24 \mathrm{~h}$ of treatment $(0,10$, and $20 \mu \mathrm{M}$ PLN), 3/7 and 9 caspases were evaluated using the Caspase-Glo 9 e 3/7 Assay (Promega, Cat. No.: G8211 and G8091) as per the manufacturer's specifications. These assays use substrates for caspases and the cleavage of the material produces a luminescence light through luciferase activity. The analyses were performed in GLOMAX (Promega; Cat. No.: GM3000). The experiments were performed in three simultaneous repetitions.

\section{Statistical analysis}

The assays, except for the RT-qPCR, were evaluated using ANOVA with Tukey test. The Kruskal-Wallis test

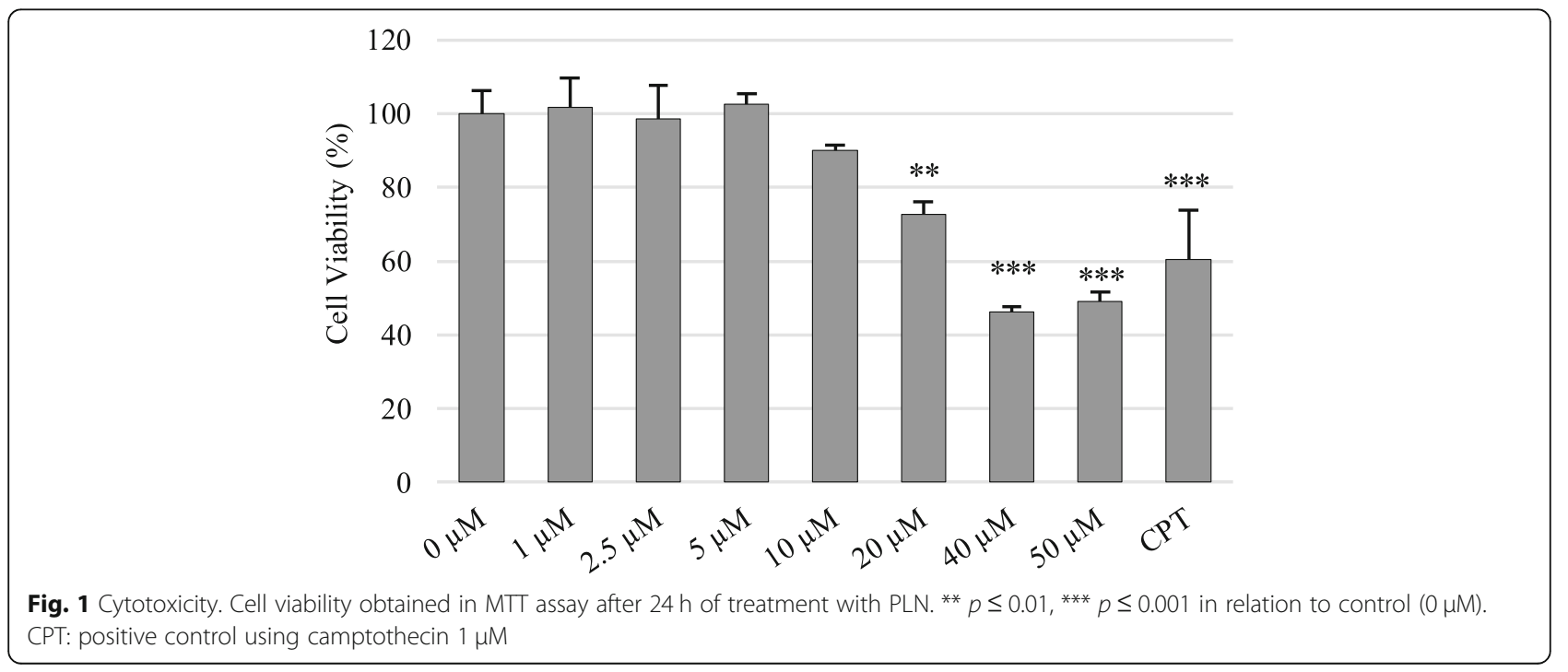




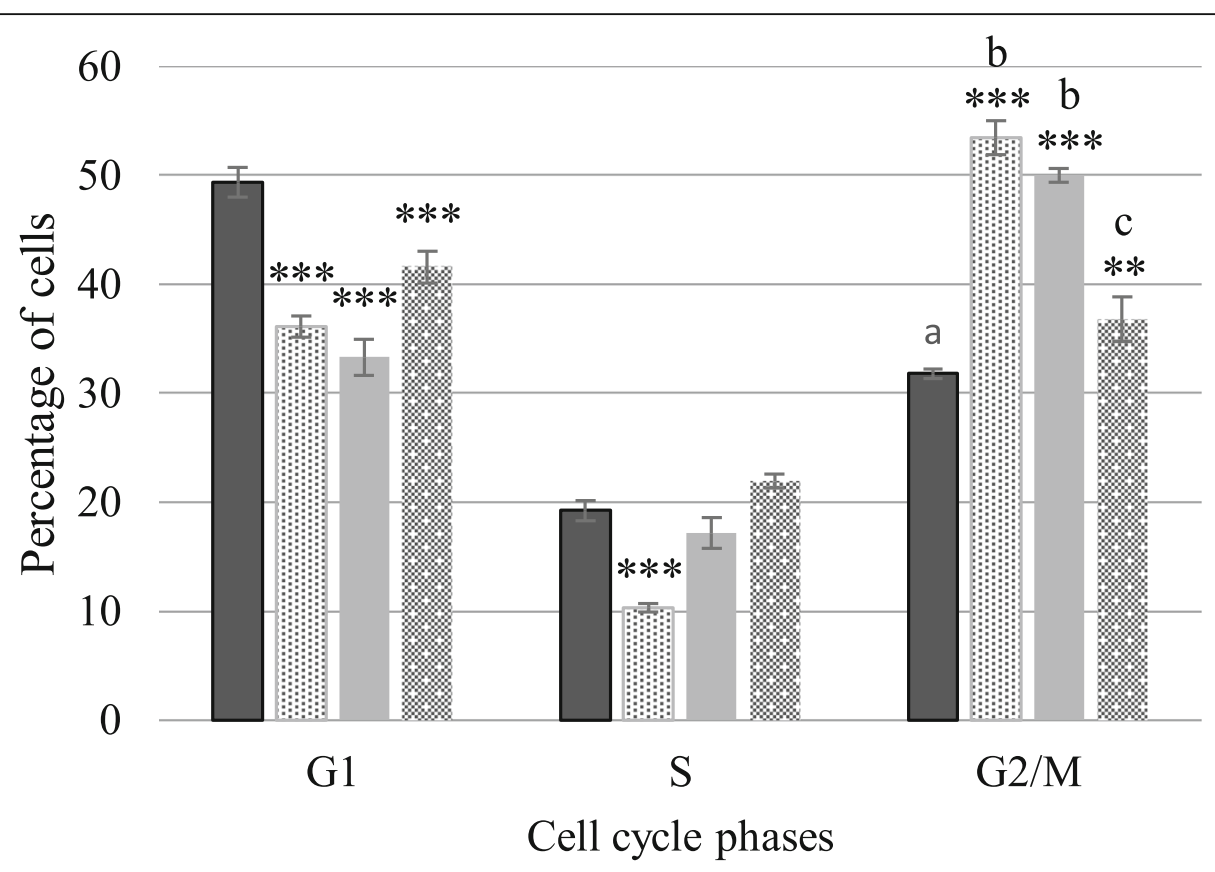

$\square 0 \mu \mathrm{M} \quad$ 国 $10 \mu \mathrm{M} \quad \square 20 \mu \mathrm{M} \quad \approx 40 \mu \mathrm{M}$

Fig. 2 Cell cycle analysis. Percentage of cells in cell cycle phases after $24 \mathrm{~h}$ of PLN treatment. Chromatin were analyzed using Propidium lodide in flow cytometry. ${ }^{* *} p \leq 0.01,{ }^{* * *} p \leq 0.001$ in relation to control $(0 \mu \mathrm{M})$. Different letters indicate significant difference

was performed for comet and the 3D assays. Relative gene expression was analyzed in REST 2009 (fold chance considered significant when $\leq 0.5$ or $\geq 2$ ). For all assays, the differences were considered significant when $P$ values were less than or equal to 0.05 .

\section{Results}

Cell viability (obtained by MTT) was significantly reduced to 72,42 , and $49 \%$ in 20,40 , and $50 \mu \mathrm{M}$ of PLN, respectively (Fig. 1). The $\mathrm{IC}_{50}$ of PLN was found to be
$40 \mu \mathrm{M}$. Corroborating the results of the MTT assay, the cell cycle (Fig. 2) showed proliferation reduction due to G2/M cell cycle arrest, a reduction in the percentages of G1 cells and increase in G2/M for all tested concentrations, and a reduction of S in $10 \mu \mathrm{M}$ of PLN. Moreover, the count of cells with the monastral spindle was increased in a PLN dose-dependent manner (Fig. 3).

In the apoptosis test (Fig. 4), all the concentrations showed a reduction in the percentages of live cells and an increase in the populations in early and late apoptosis. In

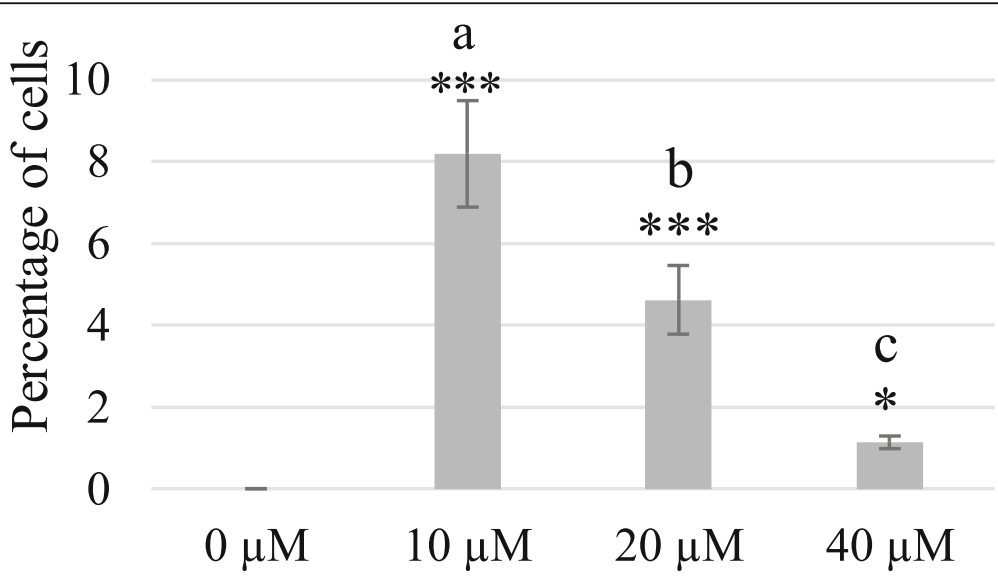

Fig. 3 Fuse spindle analysis. Cells with monastral spindle after $24 \mathrm{~h}$ of PLN treatment. Chromatin were observed and counted using Hoechst 33342 in EVOS FL Auto microscope. ${ }^{*} p \leq 0.05,{ }^{* *} p \leq 0.001$ in relation to control $(0 \mu \mathrm{M})$. Different letters indicate significant difference 


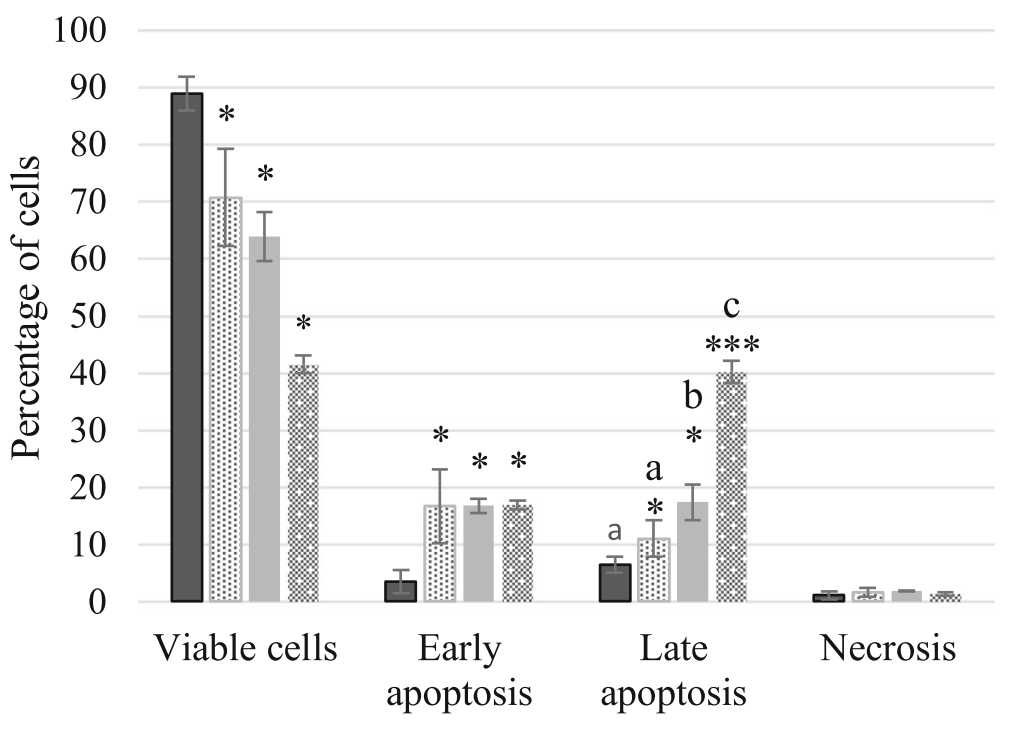

$0 \mu \mathrm{M}$ 图 $10 \mu \mathrm{M} \backsim 20 \mu \mathrm{M} \approx 40 \mu \mathrm{M}$

Fig. 4 Cell death analysis. Cell death induction after $24 \mathrm{~h}$ of PLN treatment. Cells were analyzed using PE Annexin $V$ and 7 -aad in flow cytometry. ${ }^{*} p \leq 0.05,{ }^{* *} p \leq 0.01,{ }^{* * *} p \leq 0.001$ in relation to control $(0 \mu \mathrm{M})$. Different letters indicate significant difference

late apoptosis, there was a significant difference among all the concentrations (dose-dependent effect). None of the concentrations of PLN induced necrosis in the cells.

The mitochondrial potential, which was evaluated using rhodamine 123 after $24 \mathrm{~h}$ of PLN treatment, was significantly reduced for the three analyzed concentrations (Fig. 5). The reduction in the fluorescence intensity of rhodamine can also be seen in Fig. 6, from which micrographs of the cultures are shown. Sections A, B, C, and D represent treatments at 10,20 , and $40 \mu \mathrm{M}$ PLN, respectively. In the blue fluorescence (DNA marking), the presence of nuclei with morphological patterns of cell cycle arrest by the formation of rosettes (monastral spindle, arrows in Sections B and C), the formation of pyknotic cells (chromatin evidenced by increased

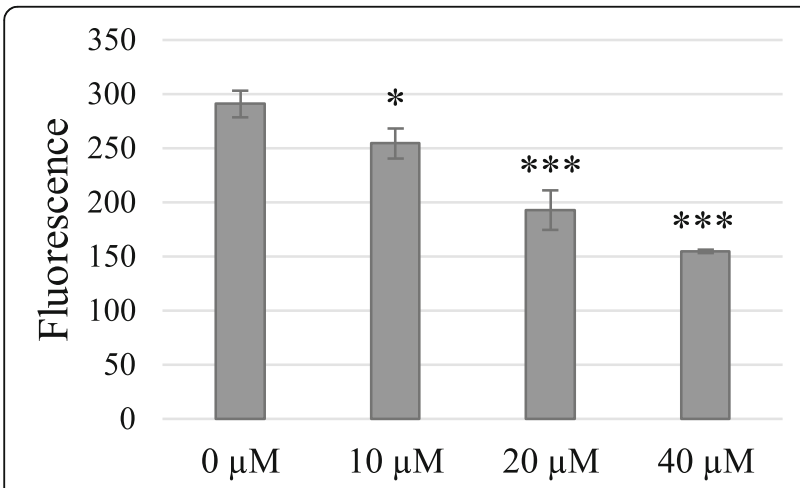

Fig. 5 Mitochondrial analysis. Mitochondrial membrane potential after $24 \mathrm{~h}$ of treatment using rhodamine $123 .{ }^{*} p \leq 0,05,{ }^{* * *} p \leq 0,001$ in relation to control $(0 \mu \mathrm{M})$ fluorescence intensity and reduction in nuclear volume), and the formation of apoptotic bodies, which represent alterations present in apoptotic cells (arrow head), were observed.

The three-dimensional culture (Fig. 7) revealed a significant reduction in the volume of spheroids that received treatments at concentrations of 20 and $40 \mu \mathrm{M}$ in relation to the control $(0 \mu \mathrm{M})$ after 24,48 , and $72 \mathrm{~h}$ of treatment. In addition, at the highest concentration tested $(40 \mu \mathrm{M})$, the spheroids presented a morphological similarity to that of the positive control $(2.5 \mu \mathrm{M}$ CPT), which showed only the presence of a "mass" containing cellular debris and absence of characteristics of living cells (for example, presence of nucleus and cytoplasmic delimitation).

The comet assay demonstrated the significant genotoxic effect of PLN on HepG2/C3A cells. Figure 8 shows the tail moment parameter with averages of $0.9,4.3$, and 11.7 for the $0,40 \mu \mathrm{M}$, and positive control, respectively.

Significant induction of ROS formation by PLN at concentrations of 20 and $40 \mu \mathrm{M}$ was evidenced, with fluorescence measurements of 1513, 1845, and 1931 for concentrations of 0,20 , and $40 \mu \mathrm{M}$, respectively (Fig. 9). ROS formation at concentrations of 10 and $20 \mu \mathrm{M}$ were not significantly different from each other; that at $40 \mu \mathrm{M}$ was significantly higher than that at the other two lower concentrations.

The data obtained in the analysis of relative gene expression are presented in Fig. 10. PLN treatment led to increased mRNA expression of genes of the cell cycle 


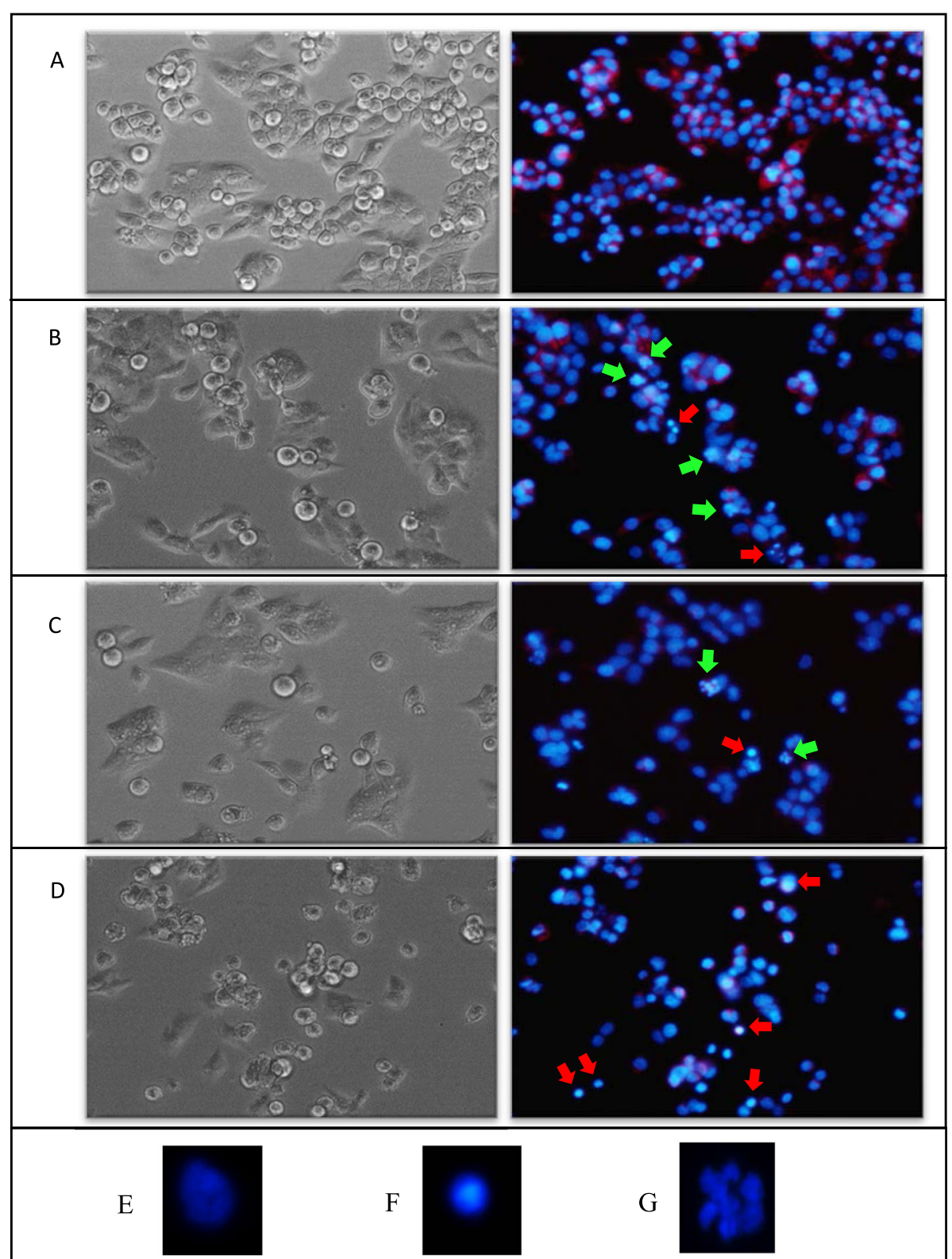

Fig. 6 Cytologic analysis in monolayer culture. Micrographs obtained after $24 \mathrm{~h}$ of treatment using the microscope EVOS FL. In the left column are the treatments containing PLN in concentrations of 0 (a), 10 (b), 20 (c) and $40 \mu \mathrm{M}$ (d) by phase contrast microscopy. Observe the morphological changes and reduction of the cell density of the cultures that received treatments containing PLN. In the right column are the same quadrants referred to the left side seen in the fluorescence microscopy; in blue are seen the chromatin marked with Hoechst 33342, and in red the marking using rhodamine. The arrows indicate the nuclei in like-rosette format and the arrow head the nuclei with morphological patterns of apoptosis (picnosis or apoptotic bodies); observe the reduction in the intensity of the red in treatments containing PLN. e interphase cell; $\mathbf{f}$ apoptotic cell (picnosis); $\mathbf{g}$ like-rosette

(CDKN1A), apoptosis (BAK1 and BBC3), DNA damage signaling (MDM2), oxidative stress (GSR and SOD1), ERS (ERN1 and HSPA14), and xenobiotic metabolism (CYP1A2 and CYP3A4); in addition, there was a reduction in the mRNA expression of CCNA2 (cell cycle).

The findings of the analysis of active caspases showed that there was a significant increase of 2.2-fold for caspase 9 in the highest tested concentration $(20 \mu \mathrm{M})$, and for caspases $3 / 7$, there was a significant increase of 2.6 and 5.5-fold at concentrations of 10 and $20 \mu \mathrm{M}$ in relation to the control (Fig. 11).

\section{Discussion}

PLN is well known for its antiproliferative, anxiolytic, and antifungal properties [19, 38]. Moreover, it is particularly known for its potential to induce oxidative 


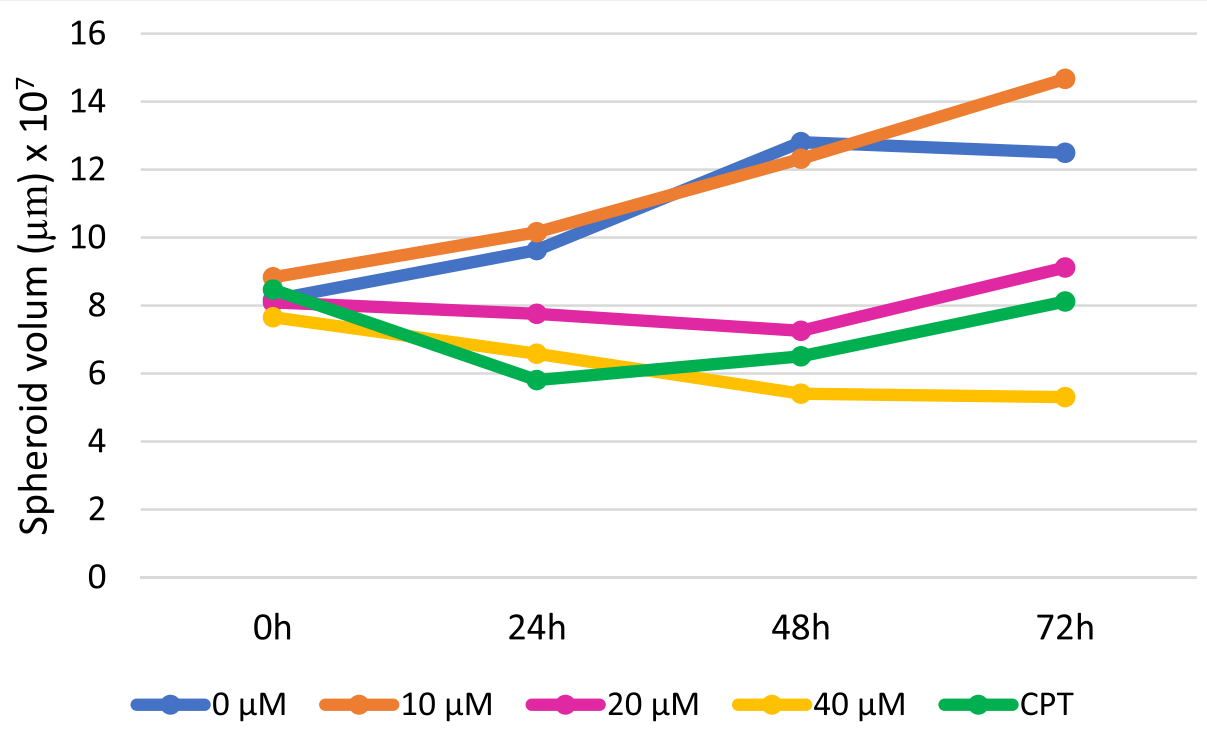

Fig. 7 Spheroids analysis. a Analysis of volumes (micrometers) of 3D cultures (spheroids) treated with PLN at concentrations of 0-40 $\mu \mathrm{M}$ before receiving the treatments $(0 \mathrm{~h})$ and after 24,48 and $72 \mathrm{~h}$. CPT: positive control using camptothecin $2.5 \mu \mathrm{M}$. b Micrographs (100 x) of the spheroids after $72 \mathrm{~h}$ of treatment

stress and result in genotoxic damages. This study showed the cytotoxic and genotoxic properties of PLN and the modulation of PLN in the transcriptional activity of key genes involved in cell proliferation, cell death, DNA damage, oxidative stress, and xenobiotic metabolism.

The cytotoxicity of PLN in HepG2/C3A was identified at concentrations $\geq 20 \mu \mathrm{M}$ [14]. found that PLN

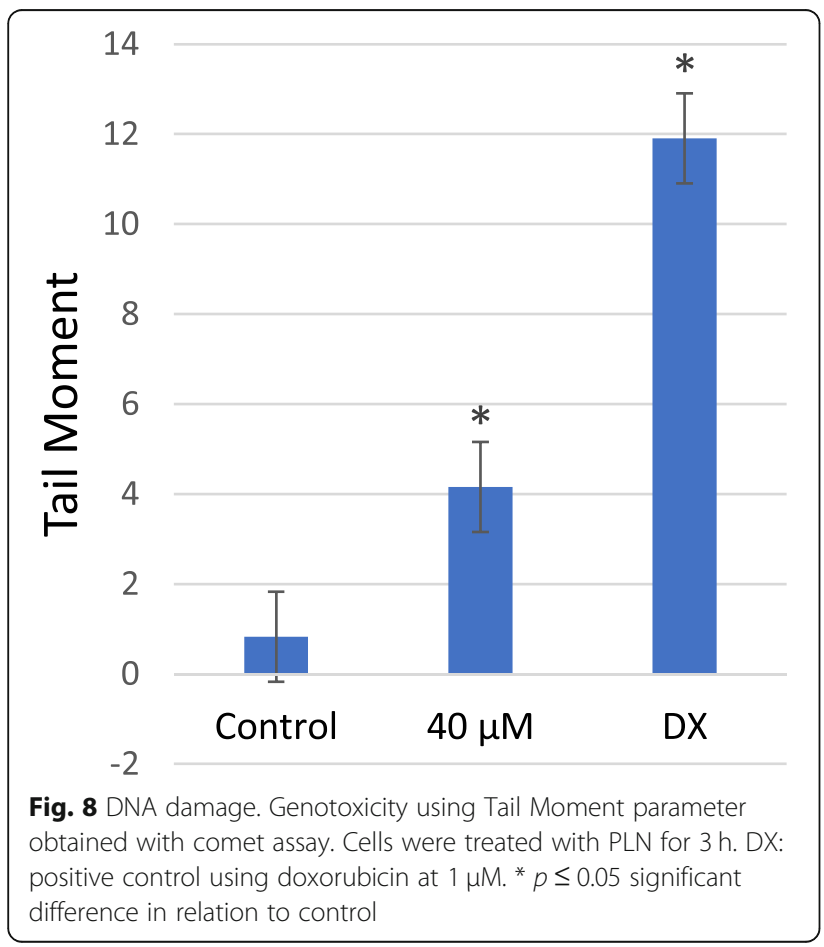

treatment for breast tumor cell lines MCF7 and BT474 significantly reduced cell viability at concentrations $\geq 4 \mu \mathrm{M}$, and the viability of the non-tumor MCF10A lineage was reduced only at concentrations $\geq 14 \mu \mathrm{M}$ [14, 20]. used several head and neck cancer strains and found PLN cytotoxicity at concentrations between 2.5 and $5 \mu \mathrm{M}$ after $24 \mathrm{~h}$ of treatment. In line U937 (histiocytic lung lymphoma), the MTT assay showed that PLN induced a significant reduction of viability only at a concentration of $20 \mu \mathrm{M}$ after $24 \mathrm{~h}$ of treatment [39]. This same assay showed a reduction in the viability of stomach cancer cell lines (MKN45 and AGS) at concentrations $\geq 20 \mu \mathrm{M}$ after $24 \mathrm{~h}$ of treatment [40]. evaluated PLN cytotoxicity in two Burkitt lymphoma cell lines by the MTS assay and observed $\mathrm{IC}_{50}$ of 2.8 and $8.5 \mu \mathrm{M}$. Despite the variable PLN cytotoxicity in the different lines mentioned, it can still be considered that there is a small threshold of toxicity for this drug, and the differences are probably due to the different sensitivities between the cell lines and assays. In addition, some studies have found lower cytotoxicity of PLN in primary nontumor cells or in non-tumor cell lines when compared to that in tumor cell lines [18, 20, 41].

From the cytotoxicity observed in the HepG2/C3A lineage, we performed further assays to understand whether the reduction in viability could be associated with reduced proliferation or induction of cell death. Our results showed that the reduction in the viability of PLN treatments was related to the reduction of cell proliferation due to the cell cycle arrest of the cells in the G2 and mitosis phases and by the induction of cell death by apoptosis. The stop in mitosis observed by the 


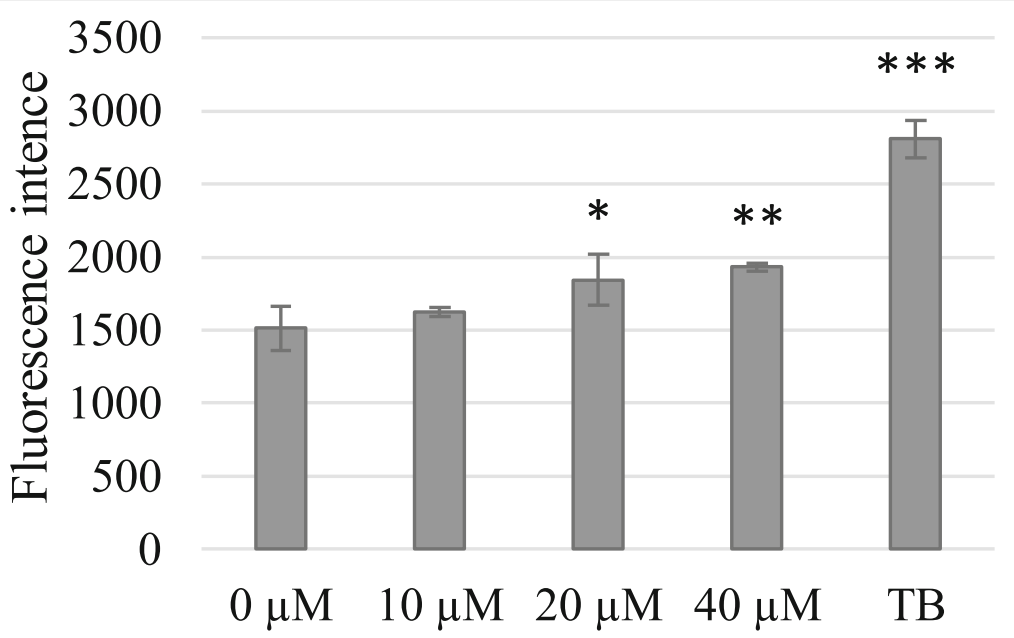

Fig. 9 Reactive oxygen species analysis. ROS detection after $24 \mathrm{~h}$ of PLN treatment. Cell were incubated with DCFDA and analyzed by flow cytometry. TB: positive control with tert-butil $200 \mu \mathrm{M}$. ${ }^{*} p \leq 0.05,{ }^{* *} p \leq 0.01,{ }^{* * *} p \leq 0.001$ indicate significant difference in relation to control

appearance of the cells in rosettes and the increase of G2/M identified by the flow cytometric analysis suggested cell cycle block also in G2, since the magnitude of the cell percentages in the analysis of the rosettes was lower than the cell percentages of G2/M observed in flow cytometry. The monastral spindle occurs when instead of the formation of the bipolar mitotic spindle, there is a central arrangement of microtubules surrounded by chromosomes [42], and this effect caused by PLN is described for the first time in our study.

Other drugs such as monastrol [43], hemiasterlin derivatives [44], $S$-trityl-L-cysteine [45], and pterocarpans [46] induce the appearance of the monastral spindle and have been studied for their potential antitumor effect. Normally, these substances act by inhibiting mitotic spindle motor proteins (kinesins) [47]. The morphological pattern confirms the data generated in flow cytometry because it was possible to observe that the increase in the cell cycle arrest in mitosis was reducing with the increase in the concentration of the drugs, and the increase of apoptotic cells occurred in a dosedependent manner.

In the mRNA expression analysis of genes involved in cell cycle control and apoptosis, we found a reduction in the expression of CCNA2 that correlated with the cell cycle arrest in the G2/M phases since it encodes cyclin A2, which is responsible for the transitions between the $\mathrm{G} 1$ and synthesis phases and between G2 and mitosis. Cyclins are proteins that associate with cyclin-dependent kinases, and their complexes act to induce cell cycle progression. Increased expression of the CDKN1A transcript, the $\mathrm{p} 21$ protein encoder, was also detected; the transcription of this protein is controlled by the p53 protein (transcription factor). The function of p21 may be related to stopping the cycle in G1 and S (through inhibition of the cyclin E/CDK2 or cyclin A/CDK2 complexes) or in G2 by transcriptional repression of EMI1 in the presence of DNA damage [48]. This confirms the cycle stop observed in this study, which in addition to that occurring in mitosis, also occurred in G2.

Analysis of the apoptosis regulation genes demonstrated increased expression of $B A K 1$ and $B B C 3$ mRNA. The proteins produced by these genes are a part of the of Bcl-2 protein family present in the mitochondria that control mitochondrial permeability. Once the permeability is increased and the extravasation of the mitochondrial content to the cytosol occurs, then the initiator caspases are activated, and subsequently, the effector caspases are activated too. The transcriptional activity of the caspase genes was not altered after treatment with PLN in HepG2/3A; however, caspases 3/7 and 9 activity demonstrated that these were increased with PLN treatment. This can occur because these proteins are normally present inside the cell, and in situations of necessity, their activations take place in a quick way, by beginning their functions in apoptosis [10]. In this study, we also observed a reduction in the mitochondrial potential of the cultures that received PLN treatments, thereby correlating the induction of apoptosis initiated by mitochondrial alterations.

In the 3-D (spheroids) evaluation, we verified that the same concentrations used in the monolayer assays could also produce antiproliferative effects. Moreover, only at concentrations $\geq 20 \mu \mathrm{M}$, a significant reduction in the spheroid volume was observed.

Induction of apoptosis by PLN is related to the induction of ERS, since an increase in the transcriptional activity of ERN1 and HSPA14 was observed. These genes encode proteins present in the ER that act as 


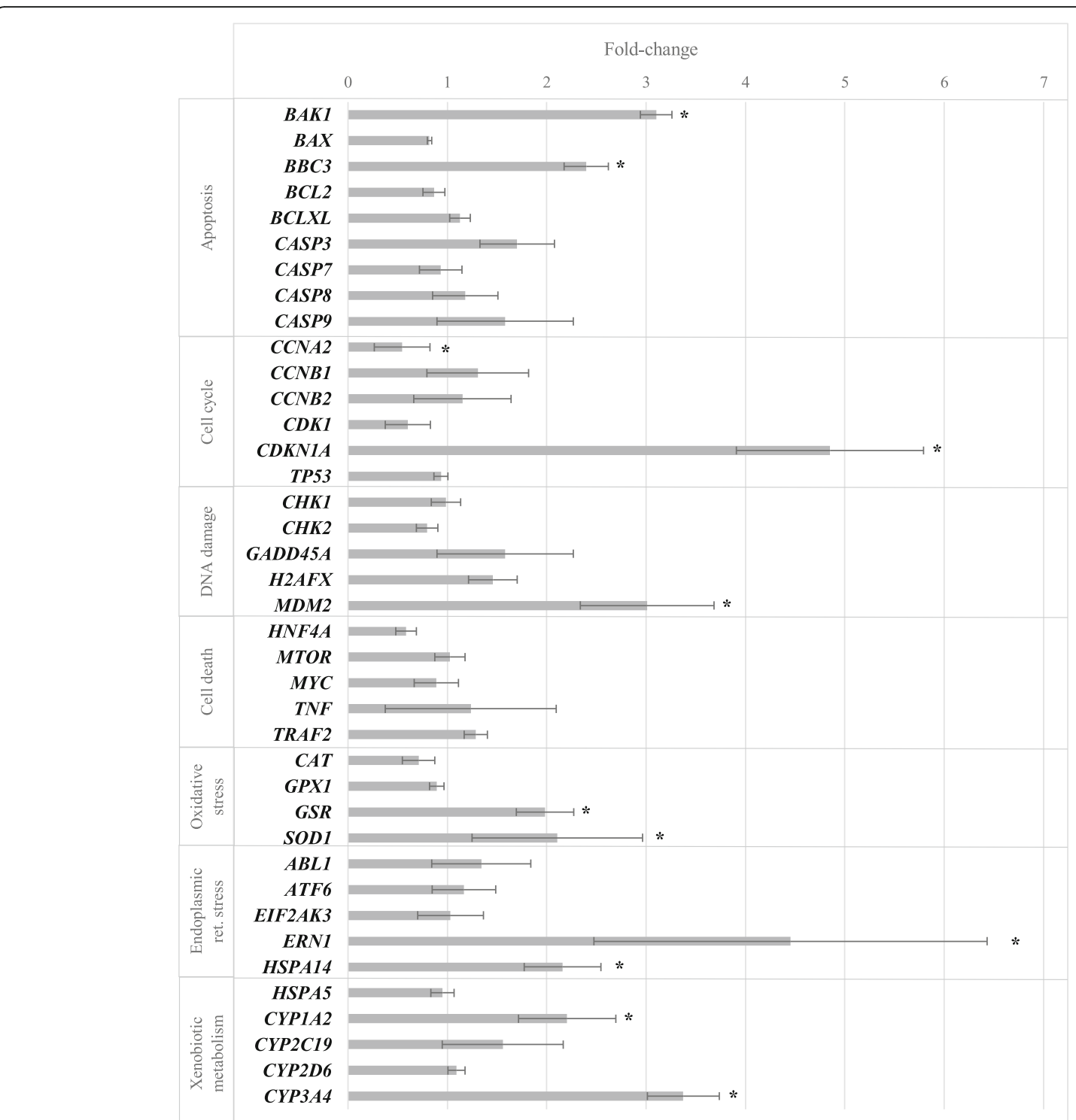

Fig. 10 mRNA expression. Relative gene expression obtained by RT-qPCR. ${ }^{*} p \leq 0.05$ indicate significant difference and fold-change $\leq 0.5$ or $\geq 2$. RPL13A and GAPDH genes were used as reference for all tested genes

sensors of altered proteins; the first one acts as a transcription factor of ERS response genes, while the second one modulates the activity of ERN1 to prevent the induction of apoptosis due to reticular stress. Several studies have also described the induction of apoptosis by ERS through PUMA protein signaling [49-51]. This is encoded by the $B B C 3$ gene whose mRNA expression was also increased in this study. The increase in HSP70, a protein resulting from HSPA14 gene expression, has also been found in the induction of monastral spindle formation through the inhibition of kinesin Eg5 in multiple myeloma cells [52] and may also be correlated with the monastral spindle formation observed in PLN treatments.
Thus, it is possible that PLN acts through several mechanisms of injury and intracellular signaling, since it induced genotoxic damage and increased ROS generation. The comet assay demonstrated the genotoxic effect of this drug and this was correlated with the observed increase in MDM2 mRNA expression; the MDM2 protein regulates the function of P53, and during DNA damage signaling, it is phosphorylated by ATM and ATR [53]. Once activated, MDM2 acts by degrading CDC25C, and the latter when inhibited, causes cell cycle arrest in G2/M [54], with monastral spindle formation being one of the cell cycle arrest patterns that may arise [55].

Induction of PLN damage through oxidative stress has been described previously [15, 19]; however, the 


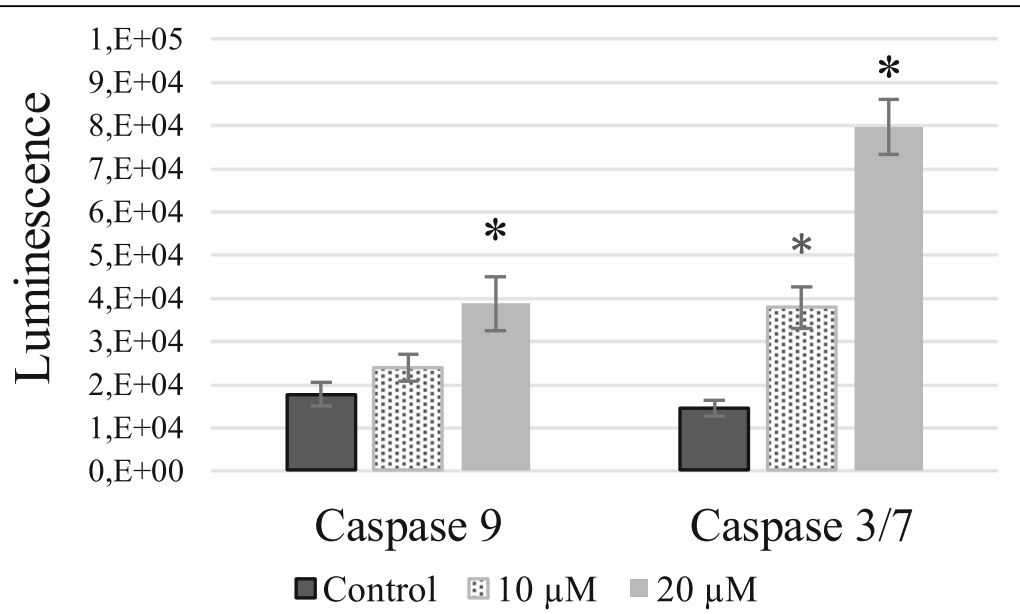

Fig. 11 Caspases activity. Active caspases 9 and $3 / 7$ evaluation. Cells received PLN for $24 \mathrm{~h}$ and were evaluated by luminescence assay. ${ }^{*} p \leq 0.05$ indicate significant difference in relation to control

increase found in HepG2/C3A of GSR and SOD1 transcripts has not yet been described for PLN treatments. GSR encodes the glutathione reductase enzyme; it acts as an antioxidant by regenerating another enzyme (glutathione oxidase) that is oxidized by the action of ROS. SOD1 encodes a metalloenzyme that transforms the superoxide radical into hydrogen peroxide, which allows other enzymes to degrade it into water and oxygen gas. The increase of these transcripts demonstrates that the cell responds to ROS elevation not only by the use of its antioxidant enzymes stored inside the cell but also by modulating its transcriptional activity to obtain a more efficient response. This is because oxidative stress can induce several harmful changes to cells [56] such as DNA damage and ERS.

The modifications observed in the expression of enzymes of hepatic metabolism are notable for determining the important toxicological parameters to be considered when proposing the development of a new drug. Cytochrome P450 enzymes are active in most human tissues and their greatest activities are in the liver, stomach, lungs, and kidneys. These enzymes oxidize endogenous or exogenous molecules, degrade xenobiotics, or activate xenobiotics in toxic substances, and contribute to the oxidative metabolism of endogenous substances such as hormones and cytokines. The existing polymorphism of these enzymes in human populations results in different profiles of bioavailability and pharmacokinetics among individuals $[57,58]$.

In this study, a significant increase in the expression of CYP1A2 and CYP3A4 transcripts was identified. The increased expression of these enzymes was related to the increased oxidation demand due to the presence of a substrate of the enzyme. Such increased enzyme/substrate interaction may reduce binding, and consequently, oxidation of other substrates. Therefore, this inhibitory action may increase the availability of other drugs and may, for example, increase the effects of these other substances. The enzymes CYP1A2 and CYP3A4 are among the major enzymes involved in the metabolism of xenobiotics (about 15 and 50\%, respectively). Two studies have described PLN action on CYP1A2 and 3A4 through the inhibitory action of PLN in the human microsomal pool $[59,60]$. This may suggest that the inhibitory action of PLN on these two enzymes stimulates the increase of the mRNA expression to meet the needs of the cell $[61,62]$.

\section{Conclusion}

In conclusion this study, the harmful effects of PLN in the HepG2/C3A cell line could be observed, with some morphological and molecular effects that are still not known in the literature. PLN induces the formation of ROS and, in response to oxidative stress, increases the expression of GSH and SOD1 genes. Thus, it is possible to infer that genotoxic damage and ERS occur due to the action of ROS on DNA and ER, presenting the modulation of the transcription of MDM2, ERN1, and HSPA14 genes. This study also shows that PLN induces the expression of cytochrome P450 genes (CYP1A2 and CYP3A4). Our findings show that PLN induces cell cycle arrest in G2 and mitosis (monastral spindle), and this effect seems to be related to the increase of MDM2. We also found unpublished data on the modulation of apoptosis via transcriptional increase of pro-apoptotic $B A K 1$ and $B B C 3$. In addition, PLN treatment also inhibited the growth of 3D culture (spheroids). Therefore, our data demonstrate the potential of PLN to be used as an antiproliferative drug. Our findings will contribute to a better applicability of PLN in anticancer therapy. 


\section{Supplementary information}

Supplementary information accompanies this paper at https://doi.org/10. 1186/s41241-020-00086-x.

Additional file 1: Table S1. Primers used in Real Time PCR reactions.

\section{Abbreviations}

CPT: Camptothecin; DCFDA: 2',7' -dichlorofluorescin diacetate; DMSO: Dimethyl sulfoxide; DXR: Doxorubicin; ERS: Endoplasmic Reticulum Stress; FBS: Fetal bovine serum; PBS: Phosphate-buffered saline; PLN: Piperlongumine; ROS: Reactive Oxygen Species

\section{Acknowledgments}

This study was supported by the Coordenação de Aperfeiçoamento de Pessoal de Nível Superior (CAPES), Conselho Nacional de Desenvolvimento Científico e Tecnológico (CNPq), Financiadora de Estudos e Projetos (FINEP), and Fundação Araucária.

\section{Authors' contributions}

M.S.M. contributed with conceptualization, supervision and article writing B.I.B. contributed with conceptualization, supervision and article writing. T.A.Z. contributed to the cell cycle analysis, cell death analysis, morphological analysis, micrograph experiments and article writing. L.A.M. contributed to the experiments cell cycle analysis and cell death analysis, as well as experiments with 3D culture. A.B. contributed to comet assay, reactive oxygen species analysis and mitochondrial potential using flow cytometry and article writing. G.C.C. contributed with the experiments and analysis of RT-qPCR and analysis of active caspases and article writing. All authors read and approved the final manuscript.

\section{Funding}

Not applicable.

\section{Availability of data and materials}

Not applicable.

\section{Ethics approval and consent to participate}

Not applicable.

\section{Consent for publication}

Not applicable.

\section{Competing interests}

The authors declare that they have no competing interests.

Received: 14 November 2019 Accepted: 13 March 2020

Published online: 06 April 2020

\section{References}

1. Weir B, Zhao X, Meyerson M. Somatic alterations in the human cancer genome. Cancer Cell. 2004;6:433-8.

2. Ouyang L, Shi Z, Zhao S, Wang FT, Zhou TT, Liu B, et al. Programmed cell death pathways in cancer: a review of apoptosis, autophagy and programmed necrosis. Cell Prolif. 2012;45:487-98.

3. Weaver BA, Cleveland DW. Decoding the links between mitosis, cancer, and chemotherapy: the mitotic checkpoint, adaptation, and cell death. Cancer Cell. 2005;8:7-12.

4. McArthur $\mathrm{H}$. An overview of HER-targeted therapy with lapatinib in breast cancer. Adv Ther. 2009:26:263-71.

5. Crafton SM, Salani R. Beyond chemotherapy: an overview and review of targeted therapy in cervical cancer. Clin Ther. 2016;38:449-58.

6. Padma W. An overview of targeted cancer therapy. Biomedicine (Taipei). 2015;5:19

7. Muilenburg DJ, Coates JM, Virudachalam S, Bold RJ. Targeting BCl-2mediated cell death as a novel therapy in pancreatic cancer. J Surg Res. 2010;163:276-81.

8. Strasser A, Cory S, Adams JM. Deciphering the rules of programmed cell death to improve therapy of cancer and other diseases. EMBO J. 2011;30: 3667-83.
9. Nonnenmacher L, Hasslacher S, Zimmermann J, Karpel-Massler G, La FerlaBruhl K, Barry SE, et al. Cell death induction in cancer therapy - past, present, and future. Crit Rev Oncog. 2016;21:253-67.

10. Rastogi RP, Richa SRP. Apoptosis: molecular mechanisms and pathogenicity EXCLI J. 2009;8:155-81.

11. Savitskaya MA, Onishchenko GE. Mechanisms of apoptosis. Biochemistry (Mosc). 2015:80:1393-405.

12. Marino G, Lopez-Otin C. Autophagy: molecular mechanisms, physiological functions and relevance in human pathology. Cell Mol Life Sci. 2004;61: 1439-54.

13. Yu L, Chen Y, Tooze SA. Autophagy pathway: cellular and molecular mechanisms. Autophagy. 2018;14:207-15.

14. Jin HO, Lee YH, Park JA, Lee HN, Kim JH, Kim JY, et al. Piperlongumine induces cell death through ROS-mediated CHOP activation and potentiates TRAlL-induced cell death in breast cancer cells. J Cancer Res Clin Oncol. 2014;140:2039-46

15. Xiong XX, Liu JM, Qiu XY, Pan F, Yu SB, Chen XQ. Piperlongumine induces apoptotic and autophagic death of the primary myeloid leukemia cells from patients via activation of ROS-p38/JNK pathways. Acta Pharmacol Sin. 2015; 36:362-74.

16. Gagat M, Halas-Wisniewska M, Zielinska W, Izdebska M, Grzanka D, Grzanka A. The effect of piperlongumine on endothelial and lung adenocarcinoma cells with regulated expression of profilin-1. Onco Targets Ther. 2018;11: 8275-92.

17. Golovine KV, Makhov PB, Teper E, Kutikov A, Canter D, Uzzo RG, et al. Piperlongumine induces rapid depletion of the androgen receptor in human prostate cancer cells. Prostate. 2013;73:23-30.

18. Liu JM, Pan F, Li L, Liu QR, Chen Y, Xiong XX, et al. Piperlongumine selectively kills glioblastoma multiforme cells via reactive oxygen species accumulation dependent JNK and p38 activation. Biochem Biophys Res Commun. 2013;437:87-93.

19. Dhillon H, Chikara S, Reindl KM. Piperlongumine induces pancreatic cancer cell death by enhancing reactive oxygen species and DNA damage. Toxicol Rep. 2014;1:309-18.

20. Roh JL, Kim EH, Park JY, Kim JW, Kwon M, Lee BH. Piperlongumine selectively kills cancer cells and increases cisplatin antitumor activity in head and neck cancer. Oncotarget. 2014;5:9227-38.

21. Bharadwaj U, Eckols TK, Kolosov M, Kasembeli MM, Adam A, Torres D, et al. Drug-repositioning screening identified piperlongumine as a direct STAT3 inhibitor with potent activity against breast cancer. Oncogene. 2015;34: 1341-53.

22. Duan C, Zhang B, Deng C, Cao Y, Zhou F, Wu L, et al. Piperlongumine induces gastric cancer cell apoptosis and G2/M cell cycle arrest both in vitro and in vivo. Tumour Biol. 2016;37:10793-804.

23. Liu D, Qiu XY, Wu X, Hu DX, Li CY, Yu SB, et al. Piperlongumine suppresses bladder cancer invasion via inhibiting epithelial mesenchymal transition and F-actin reorganization. Biochem Biophys Res Commun. 2017;494:165-72.

24. Thongsom S, Suginta W, Lee KJ, Choe H, Talabnin C. Piperlongumine induces G2/M phase arrest and apoptosis in cholangiocarcinoma cells through the ROS-JNK-ERK signaling pathway. Apoptosis. 2017;22:1473-84.

25. Song X, Gao T, Lei Q, Zhang L, Yao Y, Xiong J. Piperlongumine induces apoptosis in human melanoma cells via reactive oxygen species mediated mitochondria disruption. Nutr Cancer. 2018:70:502-11.

26. Makhov P, Golovine K, Teper E, Kutikov A, Mehrazin R, Corcoran A, et al. Piperlongumine promotes autophagy via inhibition of Akt/mTOR signalling and mediates cancer cell death. Br J Cancer. 2014;110:899-907.

27. Shrivastava S, Kulkarni $P$, Thummuri $D$, Jeengar MK, Naidu VG, Alvala M, et al. Piperlongumine, an alkaloid causes inhibition of PI3 K/Akt/mTOR signaling axis to induce caspase-dependent apoptosis in human triplenegative breast cancer cells. Apoptosis. 2014;19:1148-64

28. Lewis KM, Bharadwaj U, Eckols TK, Kolosov M, Kasembeli MM, Fridley C, et al. Small-molecule targeting of signal transducer and activator of transcription (STAT) 3 to treat non-small cell lung cancer. Lung Cancer. 2015:90:182-90.

29. Wang F, Mao Y, You Q, Hua D, Cai D. Piperlongumine induces apoptosis and autophagy in human lung cancer cells through inhibition of PI3K/Akt/ mTOR pathway. Int J Immunopathol Pharmacol. 2015;28:362-73.

30. Karki K, Hedrick E, Kasiappan R, Jin UH, Safe S. Piperlongumine induces reactive oxygen species (ROS)-dependent downregulation of specificity protein transcription factors. Cancer Prev Res (Phila). 2017; 10:467-77. 
31. Zhou Y, Huang F, Yang Y, Wang P, Zhang Z, Tang Y, et al. Paraptosisinducing nanomedicine overcomes cancer drug resistance for a potent cancer therapy. Small. 2018;14:1702446.

32. Mosmann T. Rapid colorimetric assay for cellular growth and survival: application to proliferation and cytotoxicity assays. J Immunol Methods. 1983:65:55-63.

33. Darzynkiewicz Z, Traganos F, Staiano-Coico L, Kapuscinski J, Melamed MR. Interaction of rhodamine 123 with living cells studied by flow cytometry. Cancer Res. 1982;42:799-806

34. Latt SA, Wohlleb JC. Optical studies of the interaction of 33258 Hoechst with DNA, chromatin, and metaphase chromosomes. Chromosoma. 1975;52: 297-316.

35. Bainbridge DR, Macey MM. Hoechst 33258: a fluorescent nuclear counterstain suitable for double-labelling immunofluorescence. J Immunol Methods. 1983;62:193-5.

36. Collins AR, Oscoz AA, Brunborg G, Gaivao I, Giovannelli L, Kruszewski M, et al. The comet assay: topical issues. Mutagenesis. 2008;23:143-51.

37. Biazi BI, Zanetti TA, Baranoski A, Corveloni AC, Mantovani MS. Cis-Nerolidol induces endoplasmic reticulum stress and cell death in human hepatocellular carcinoma cells through extensive CYP2C19 and CYP1A2 oxidation. Basic Clin Pharmacol Toxicol. 2017:121:334-41.

38. Bezerra DP, Pessoa C, de Moraes MO, Saker-Neto N, Silveira ER, Costa-Lotufo LV. Overview of the therapeutic potential of piplartine (piperlongumine). Eur J Pharm Sci. 2013;48:453-63.

39. Wang H, Wang Y, Gao H, Wang B, Dou L, Li Y. Piperlongumine induces apoptosis and autophagy in leukemic cells through targeting the PI3K/Akt/ mTOR and p38 signaling pathways. Oncol Lett. 2018;15:1423-8.

40. Han SS, Son DJ, Yun H, Kamberos NL, Janz S. Piperlongumine inhibits proliferation and survival of Burkitt lymphoma in vitro. Leuk Res. 2013; 37:146-54.

41. Chen $Y$, Liu JM, Xiong XX, Qiu XY, Pan F, Liu D, et al. Piperlongumine selectively kills hepatocellular carcinoma cells and preferentially inhibits their invasion via ROS-ER-MAPKs-CHOP. Oncotarget. 2015;6: 6406-21.

42. Mayer TU, Kapoor TM, Haggarty SJ, King RW, Schreiber SL, Mitchison TJ. Small molecule inhibitor of mitotic spindle bipolarity identified in a phenotype-based screen. Science. 1999;286:971-4.

43. Cochran JC, Gatial JE 3rd, Kapoor TM, Gilbert SP. Monastrol inhibition of the mitotic kinesin Eg5. J Biol Chem. 2005;280:12658-67.

44. Hsu LC, Durrant DE, Huang CC, Chi NW, Baruchello R, Rondanin R, et al. Development of hemiasterlin derivatives as potential anticancer agents that inhibit tubulin polymerization and synergize with a stilbene tubulin inhibitor. Investig New Drugs. 2012;30:1379-88.

45. Shimizu M, Ishii H, Ogo N, Unno Y, Matsuno K, Sawada J, et al. S-trityl-Lcysteine derivative induces caspase-independent cell death in K562 human chronic myeloid leukemia cell line. Cancer Lett. 2010;298:99-106.

46. Militao GC, Prado MP, Pessoa C, de Moraes MO, Silveira ER, Lima MA, et al. Pterocarpans induce tumor cell death through persistent mitotic arrest during prometaphase. Biochimie. 2014;104:147-55.

47. Balakumar C, Ramesh M, Tham CL, Khathi SP, Kozielski F, Srinivasulu C, et al. Ligand- and structure-based in silico studies to identify kinesin spindle protein (KSP) inhibitors as potential anticancer agents. J Biomol Struct Dyn. 2018;36(14):3687-704.

48. Lee J, Kim JA, Barbier V, Fotedar A, Fotedar R. DNA damage triggers p21WAF1-dependent Emi1 down-regulation that maintains G2 arrest. Mol Biol Cell. 2009;20:1891-902.

49. Reimertz C, Kogel D, Rami A, Chittenden T, Prehn JH. Gene expression during ER stress-induced apoptosis in neurons: induction of the $\mathrm{BH}$-only protein Bbc3/PUMA and activation of the mitochondrial apoptosis pathway. J Cell Biol. 2003;162:587-97.

50. Li J, Lee B, Lee AS. Endoplasmic reticulum stress-induced apoptosis: multiple pathways and activation of p53-up-regulated modulator of apoptosis (PUMA) and NOXA by p53. J Biol Chem. 2006;281:7260-70.

51. Xu C, Bailly-Maitre B, Reed JC. Endoplasmic reticulum stress: cell life and death decisions. J Clin Invest. 2005;115:2656-64.

52. Liu M, Aneja R, Liu C, Sun L, Gao J, Wang H, et al. Inhibition of the mitotic kinesin Eg5 up-regulates Hsp70 through the phosphatidylinositol 3-kinase/ Akt pathway in multiple myeloma cells. J Biol Chem. 2006;281:18090-7.

53. Cheng $\mathrm{Q}$, Chen J. Mechanism of p53 stabilization by ATM after DNA damage. Cell Cycle. 2010;9:472-8.
54. Giono LE, Resnick-Silverman L, Carvajal LA, St Clair S, Manfredi JJ. Mdm2 promotes $\mathrm{Cdc} 25 \mathrm{C}$ protein degradation and delays cell cycle progression through the G2/M phase. Oncogene. 2017;36:6762-73.

55. Cazales M, Boutros R, Brezak MC, Chaumeron S, Prevost G, Ducommun B. Pharmacologic inhibition of CDC25 phosphatases impairs interphase microtubule dynamics and mitotic spindle assembly. Mol Cancer Ther. 2007; 6:318-25.

56. Hauck AK, Bernlohr DA. Oxidative stress and lipotoxicity. J Lipid Res. 2016;57: 1976-86.

57. Denison MS, Whitlock JP Jr. Xenobiotic-inducible transcription of cytochrome P450 genes. J Biol Chem. 1995;270:18175-8.

58. Guengerich FP. Common and uncommon cytochrome $\mathrm{P} 450$ reactions related to metabolism and chemical toxicity. Chem Res Toxicol. 2001;14: 611-50.

59. de Lima MF, Habenschus MD, Barth T, Marques LM, Pilon AC, da Silva BV, et al. Metabolic profile and safety of piperlongumine. Sci Rep. 2016;6:33646.

60. Song M, Hwang JY, Lee MY, Jee JG, Lee YM, Bae JS, et al. In vitro inhibitory effect of piperlonguminine isolated from Piper longum on human cytochrome P450 1A2. Arch Pharm Res. 2014;37:1063-8.

61. Faber MS, Jetter A, Fuhr U. Assessment of CYP1A2 activity in clinical practice: why, how, and when? Basic Clin Pharmacol Toxicol. 2005;97: 125-34

62. Plant NJ, Gibson GG. Evaluation of the toxicological relevance of CYP3A4 induction. Curr Opin Drug Discov Devel. 2003;6:50-6.

\section{Publisher's Note}

Springer Nature remains neutral with regard to jurisdictional claims in published maps and institutional affiliations.
Ready to submit your research? Choose BMC and benefit from:

- fast, convenient online submission

- thorough peer review by experienced researchers in your field

- rapid publication on acceptance

- support for research data, including large and complex data types

- gold Open Access which fosters wider collaboration and increased citations

- maximum visibility for your research: over $100 \mathrm{M}$ website views per year

At $\mathrm{BMC}$, research is always in progress.

Learn more biomedcentral.com/submissions 